\title{
Aplikasi Beberapa Bentuk Formulasi Trichoderma spp Dalam Mengendalikan Penyakit Layu Fusarium Pada Tanaman Tomat
}

\author{
Application of Several Forms by Trichoderma spp Formulation in Controlling \\ Fusarium \\ Wilt Disease on Tomato Plants \\ Muhammad Fazil $^{1}$, Rina Sriwati ${ }^{1}$, Tjut Chamzurni ${ }^{1 *}$ \\ ${ }^{1}$ Program Studi Agroteknologi, Fakultas Pertanian, Universitas Syiah Kuala
}

\begin{abstract}
ABSTRAK
Fusarium oxysporum f.sp. lycopersici (Fol) adalah salah satu patogen tular tanah yang sangat berbahaya bagi tanaman tomat, hal itu dikarenakan patogen ini mampu bertahan dalam jangka waktu yang lama di dalam tanah. Salah satu alternatif pengendalian secara biologi yang ramah lingkungan adalah dengan cara memanfaatkan cendawan antagonis sebagai agen biokontrol yaitu Trichoderma spp. penggunaan cendawan antagonis sebagai agen hayati harus dalam bentuk formula yang tepat dengan bahan yang mudah tersedia. Penelitian ini bertujuan untuk mengetahui pengaruh aplikasi beberapa bentuk formulasi Trichoderma spp dalam mengendalikan penyakit layu fusarium pada tanaman tomat. Penelitian ini menggunakan Rancangan Acak Lengkap pola non faktorial yang terdiri dari 4 perlakuan dengan menggunakan 5 ulangan, setiap ulangan terdiri dari 4 unit tanaman. Susunan perlakuan bentuk formulasi berbahan aktif Trichoderma spp yaitu F0 = Kontrol (tanpa perlakuan),F1 = Formulasi pelet daun katuk $3 \mathrm{~g}( \pm 10$ butir $) /$ polibag, F2 = Formulasi padat jagung kering $3 \mathrm{~g} /$ polibag dan F3 = Formulasi cair produk komersil $100 \mathrm{ml} /$ polibag. Hasil penelitian menunjukkan bahwa aplikasi beberapa bentuk formulasi Trichoderma spp mampu memberikan pengaruh yang nyata terhadap persentase layu tanaman dan tinggi tanaman serta persentase batang yang xylemnya terdiskolorasi.
\end{abstract}

Kata kunci : Formulasi, Trichoderma spp, Layu fusarium dan Tanaman tomat

Abstract. Fusarium oxysporum f.sp. lycopersici (Fol) is one of the soil pathogens that is very harmful for tomato plants, it is because these pathogens are able to survive for a long time in the soil. One of the alternative biological controls that are environmentally friendly is by utilizing the antagonist fungus as a biocontrol agent that is Trichoderma spp. the use of antagonistic fungi as biological agents should be in the form of the right formula with easily available materials. This study aims to determine the effect of application of some form of Trichoderma spp formulation in controlling fusarium wilt disease in tomato plants. This research uses Completely Randomized Design of non factorial pattern consisting of 4 treatments using 5 replications, each replication consisting of 4 plant units. the active formulation by several form formulation of Trichoderma spp is F0 = Control (without treatment), F1 = Leaf pelet formulation $3 \mathrm{~g}(+10$ grain) $/$ polybag, F2 = Dry corn solid formula $3 \mathrm{~g} /$ polybag and $\mathrm{F} 3=$ Commercial liquid product formulation $100 \mathrm{ml} /$ polybag. The results showed that the application of some form of formulation Trichoderma spp able to give a real effect on the percentage of wilting plants and plant height as well as the percentage of stems that discoloration on xylem.

Key words: Formulation, Trichoderma spp, Fusarium Wilt and Tomato Plants

\section{PENDAHULUAN}

Produksi tomat di provinsi Aceh selama periode 2013-2014 mengalami penurunan sebesar $13.8 \%$. Pada tahun 2013 mampu berproduksi 34.846 ton, kemudian menurun pada tahun 2014 yang hanya mampu berproduksi 30.035 ton (BPS, 2016). Menurunnya produksi tomat disuatu provinsi akan dapat berdampak terhadap penurunan produksi tomat pada skala nasional.

Salah satu penyebab menurunnya produksi tomat di Indonesia adalah gangguan cendawan patogen Fusarium sp yang menyebabkan penyakit layu fusarium (Semangun, 
Agrios, 2005). Menurut Wibowo (2005), penyakit ini mampu menimbulkan kerusakan yang parah pada tanaman tomat sampai menimbulkan kerugian 20-30\%.

Pengendalian dengan cara biologi dilaporkan sangat efektif dan belum ada yang melaporkan timbulnya ketahanan cendawan patogen terhadap agens pengendali hayati (Freeman et al., 2002). Salah satu alternatif pengendalian secara biologi yang ramah lingkungan adalah dengan cara memanfaatkan cendawan antagonis sebagai agen biokontrol yaitu Trichoderma spp.

Cendawan antagonis Trichoderma spp mempunyai kemampuan sebagai parasit dan bersifat antibiosis karena menghasilkan enzim yang secara aktif mampu mendegradasi sel-sel patogen, sehingga menyebabkan lisisnya sel-sel cendawan patogen dan mengeluarkan trikotoksin yang dapat mematikan cendawan patogen (Saragih et al., 2006; Liswarni et al., 2007).

Pembuatan formula agen pengendali hayati dalam bentuk sediaan pelet dan cair bertujuan agar penggunaannya lebih praktis pada saat aplikasi dan jumlah biomassanya lebih terukur atau dapat terkontrol (Rusli dan Trizelia, 2009). Selain itu, penggunaan cendawan antagonis sebagai agen hayati dianjurkan harus dalam bentuk formula yang tepat dengan bahan yang mudah tersedia (Lewis dan Papavizas, 1983).

\section{METODE PENELITIAN}

\section{Waktu dan Tempat Penelitian}

Penelitian ini dilaksanakan sejak November 2016 sampai dengan Maret 2017 di Laboratorium Penyakit Tanaman Program Studi Proteksi Tanaman Fakultas Pertanian Universitas Syiah Kuala dan Rumah Kasa Kebun Percobaan Fakultas Pertanian Universitas Syiah Kuala.

\section{Bahan dan Alat Penelitian}

Alat-alat yang digunakan dalam penelitian ini adalah timbangan, penggaris, gembor, alat tulis, ember, oven, pisau scapel, cawan petri, mikroskop, timbangan digital, Laminar air flow, autoclave, pinset, blender, inkubator, haemocytometer.

Bahan-bahan yang digunakan dalam penelitian ini adalah sampel tanah entisol, kompos, pupuk NPK (pupuk majemuk), polibag, benih tomat varietas Servo, molase, tepung bawang putih, Potato Dextrose Agar (PDA), isolat fusarium, isolat Trichoderma harzianum, Octobacter, tepung daun katuk, Beras, Jagung pecah, kertas buram, aluminium foil, plastik wrap, tisu, sarung tangan, alkohol.

\section{Rancangan Penelitian}

Rancangan yang digunakan adalah Rancangan Acak Lengkap pola non faktorial yang terdiri dari 4 perlakuan dengan menggunakan 5 ulangan, setiap ulangan terdiri dari 4 unit tanaman. Susunan perlakuan bentuk formulasi berbahan aktif Trichoderma spp yaitu F0 = Kontrol (tanpa perlakuan),F1 = Formulasi pelet daun katuk $3 \mathrm{~g}( \pm 10$ butir)/polibag, F2 = Formulasi padat jagung kering $3 \mathrm{~g} /$ polibag dan F3 = Formulasi cair produk komersil 100 $\mathrm{ml} /$ polibag.

\section{Pelaksanaan Penelitian}

\section{Persiapan Isolat Patogen $F$. oxysporum $f$. sp lycopersici (Fol)}

Isolat cendawan Fol yang digunakan berasal dari Laboratorium Penyakit Tanaman Fakultas Pertanian Unsyiah kemudian diperbanyak. Isolat cendawan Fol yang sudah murni diperbanyak secara aseptik dengan mengambil sebagian kecil menggunakan pisau scapel lalu 
dipindahkan pada cawan petri diameter $9 \mathrm{~cm}$ yang berisi media PDA dan diinkubasikan selama 7 hari pada suhu ruang $\left(25^{\circ} \mathrm{C}\right)$ untuk perbanyakan.

Isolat tersebut akan dibiakkan pada media beras sebanyak $1 \mathrm{~kg}$. Caranya, beras dicuci bersih dan ditiriskan sampai kering, kemudian dimasukkan ke dalam plastik tahan panas untuk disterilkan ke dalam autoklaf dengan suhu 121oC selama 30 menit. Setelah itu beras didinginkan di ruangan yang steril, lalu Fol dibiakkan ke dalam substrat beras dan diinkubasikan selama 30 hari ( Chamzurni et al., 2010).

\section{Perbanyakan Trichoderma harzianum}

Sebelum diberikan perlakuan terlebih dahulu dilakukan pengambilan sampel tanah awal dan analisis sifat-sifat fisika tanah. Pengambilan sampel tanah awal dilakukan pada tanggal 22 Mei 2016. Analisis sifat fisika tanah awal dilakukan meliputi penetapan bobot isi tanah, penetapan porositas tanah, penetapan kadar air tanah, penetapan permeabilitas tanah, penetapan indeks stabilitas agregat tanah serta partikel density. Sedangkan analisis tanah akhir dilakukan setelah panen.

\section{Pembuatan dan Persiapan Beberapa Bentuk Formulasi Berbahan Aktif Trichoderma spp}

Media F1 (formulasi pelet) di buat dengan komposisi bahan terdiri dari daun katuk yang sudah dijemur dibawah sinar matahari hingga kering sampai daun bisa dipatahkan lalu digiling menggunakan blender dan diayak dengan ayakan 6 mesh menjadi tepung daun katuk. Adonan dibuat dengan cara mencampurkan dedak $31.0 \mathrm{~g}$, tepung daun katuk $10.5 \mathrm{~g}$, Molase $15 \mathrm{ml}$ dan air steril $42 \mathrm{ml}$ diaduk hingga homogen kemudian dibungkus dengan plastik tahan panas, lalu disterilkan dalam autoklaf dengan suhu $121^{\circ} \mathrm{C}$ selama 30 menit. Kemudian $T$. harzianum yang telah berusia 5 hari pada medium PDA, diambil suspensi sebanyak $2 \mathrm{ml}$ lalu dimasukkan ke dalam bahan adonan yang sudah disterilkan tadi, selanjutnya diaduk supaya cendawan tersebar secara merata pada media. Pembuatan pelet di dalam ruang laminar air flow secara aseptik. Pellet yang sudah jadi tersebut kemudian disimpan dalam inkubator selama 48 jam dengan suhu $30^{\circ} \mathrm{C}$ lalu pelet $T$. harzianum dikeluarkan dari sedotan dan dimasukkan ke dalam plastik klem (Soekarno et al., 2014).

Media F2 (formulasi jagung) dibuat dengan cara $T$. harzianum diperbanyak dalam cawan petri yang berisi media PDA dan dibiakkan pada media jagung, dengan cara, jagung pecah sebanyak $100 \mathrm{~g}$ dicuci bersih dan ditiriskan sampai kering, kemudian dimasukkan ke dalam plastik tahan panas untuk disterilkan. Setalah itu jagung didinginkan di ruangan yang steril, selanjutnya $T$. harzianum yang ditumbuhkan didalam satu cawan petri lalu di potong kecil-kecil kemudian dimasukkan kedalam plastik tahan panas yang berisi substrat jagung dan diinkubasikan selama 14 hari.

Media F3 (formulasi cair) merupakan salah satu produk komersil yang berasal dari Wonogiri - Jawa Tengah dengan komposisi yang terdiri dari ekstrak kentang, gula, air murni biang Trichoderma dengan kandungan bahan aktif Trichoderma spp. 3.15 x $107 \mathrm{konidia} / \mathrm{ml}$, T. harzianum 2.15 x 107 konidia/ml dan T. viridae 1.15 x 107 konidia $/ \mathrm{ml}$.

\section{Persemaian}

Persemaian benih tomat dilakukan dalam polibag volume $500 \mathrm{~g}$, dengan menggunakan medium tanah yang telah dikeringanginkan dan dicampur kompos dengan perbandingan 2:1. Kemudian bibit tomat yang telah berumur 28 hari di persemaian akan dipindahkan ke polibag volume $10 \mathrm{~kg}$.

\section{Persiapan Media Tanam}


Tanah yang akan digunakan sebagai media tanam adalah tanah lapisan atas dengan kedalaman sampai $20 \mathrm{~cm}$ (top soil) dari jenis Entisol yang didapatkan dari Kebun Percobaan Fakultas Pertanian Unsyiah lalu dikeringanginkan selama 7 hari. Tanah yang telah dikeringanginkan tersebut kemudian dibersihkan dari sisa-sisa tanaman. Tanah yang telah dibersihkan dicampur dengan pupuk kompos dengan perbandingan 2:1 kemudian diisi ke dalam media tanam polibag volume $10 \mathrm{~kg}$.

\section{Aplikasi Beberapa Bentuk Formulasi Berbahan Aktif Trichoderma spp}

Perlakuan F1 diberikan dengan cara membenamkan pelet $3 \mathrm{~g}( \pm 10$ butir $)$ dengan kerapatan $10^{7}$ konidia/ml ke dalam media tanam sedalam $3 \mathrm{~cm}$, perlakuan $\mathrm{F} 2$ juga dengan membenamkan sebanyak $3 \mathrm{~g}$ media jagung kering dengan kerapatan $10^{7} \mathrm{konidia} / \mathrm{ml}$ ke dalam media tanam, F3 diberikan sebanyak $100 \mathrm{ml} /$ tanaman sesuai dengan anjuran produk yaitu 400 liter/ha dengan kerapatan $10^{7} \mathrm{konidia} / \mathrm{ml}$ lalu disiramkan pada media tanam dan selanjutnya pada area perakaran sedangkan F0 (kontrol) tanpa penggunaan cendawan antagonis. Aplikasi formulasi diberikan secara periodik menggunakan dosis yang sama sebanyak 2 kali yaitu pada saat 1 minggu sebelum inokulasi Fol pada media tanam dan selanjutnya 1 minggu setelah inokulasi Fol, Sedangkan Fol diinokulasikan bersamaan dengan hari tanam.

\section{Inokulasi F. oxysporum f. lycopersici (Fol) Pada Media Tanam}

Fol diinokulasi dengan cara patogen tersebut menaburkan ke sekitaran lubang tanam serta dibenamkan ke dalam tanah sedalam $3 \mathrm{~cm}$ sebanyak $10 \mathrm{~g}$ (Susanna et al., 2010) subtrat beras dengan kerapatan 2.031 x $107 \mathrm{konidia} / \mathrm{ml}$ pada setiap media tanam bersamaan dengan hari tanam. Untuk menjaga kelembaban dan menghindari kontaminasi, tanah yang telah diinokulasikan ditutup dengan plastik transparan (Alfizar et al., 2011).

\section{Pemeliharaan Tanaman}

Pemeliharaan tanaman dilakukan dengan melakukan penyiraman sebanyak 2 kali yaitu pada pagi dan sore hari atau disesuaikan kondisi cuaca (hujan). Penyiangan gulma dilakukan dengan mencabut gulma yang tumbuh di dalam polibag. pupuk NPK (16:16:20) diberikan sebanyak $10 \mathrm{~g}$ per tanaman pada umur 21 hari.

\section{Peubah yang Diamati}

\section{Masa Inkubasi (Hari)}

Diamati setelah tanaman tomat diinokulasi Fol sampai awal munculnya gejala penyakit layu fusarium yang ditandai dengan gejala awal yaitu daun menguningnya (klorosis) pada bagian bawah tanaman sehingga mengakibatkan matinya jaringan daun (gejala nekrosis) lalu daun akan kering.

\section{Persentase Tanaman Layu (\%)}

Pengamatan kejadian penyakit yang terserang Fol dilakukan sejak 7 hari setelah inokulasi Fol pada media tanam dengan interval pengamatan selama 7 hari sampai hari ke 49. Pengamatan pada tanaman yang terserang diamati dengan gejala yang nampak pada bagian daun, tulang-tulang daun dan batang tanaman. Kejadian penyakit akan ditentukan dengan rumus :

$\mathrm{TL}=\mathrm{n} / \mathrm{N} \times 100 \%$

Keterangan :

$\mathrm{TL}=$ Persentase tanaman layu

$\mathrm{n}=$ Jumlah tanaman yang layu,

$\mathrm{N}$ = Jumlah tanaman yang diamati. 


\section{Tinggi Tanaman Tomat (cm)}

Pengamatan tinggi tanaman dilakukan dengan cara mengukur dari mulai pangkal batang di atas permukaan tanah sampai ke tajuk tertinggi tanaman yang akan dilakukan pada 7, 14 dan 21 hari setelah inokulasi (MST) dengan menggunakan penggaris ukuran 1 meter.

\section{Berat Buah Tomat Per Tanaman (g)}

Berat buah tomat per tanaman dilakukan dengan cara menimbang berat buah per tanaman setiap kali panen, kemudian dijumlahkan keseluruhannya. Panen dilakukan sebanyak 6 kali pada umur 56, 63, 70, 77, 84 dan 91 Hari Setelah Tanam (HST).

\section{Persentase Batang yang XylemnyaTerdiskolorasi (\%)}

Pengamatan ini akan dilakukan pada akhir penelitian yaitu dengan cara tanaman tomat dicabut, selanjutnya pangkal tanaman dipotong secara membujur, lalu dibelah ke arah batang dan akar. Kemudian dihitung jaringan xylem yang terdiskolorasi yang berwarna cokelat dengan menggunakan rumus :

$\mathrm{XD}=\mathrm{a} / \mathrm{b} \times 100 \%$

Keterangan :

$\mathrm{XD}=$ Xylem diskolorasi $(\%)$,

a = Jumlah batang yang xylemnya terdiskolorasi,

$\mathrm{b}=$ Jumlah batang yang diamati.

\section{Analisis Data}

Seluruh hasil pengamatan dari tiap peubah akan dianalisis menggunakan sidik ragam menggunakan program Microsoft Excel, bila terdapat perbedaan yang nyata maka akan dilanjutkan dengan uji beda nyata terkecil (BNT) pada taraf 0,05.

\section{HASIL DAN PEMBAHASAN}

\section{Masa Inkubasi}

Hasil pengamatan terhadap masa inkubasi menunjukkan bahwa formulasi Trichoderma spp tidak berpengaruh nyata terhadap masa inkubasi. Rata-rata masa inkubasi akibat aplikasi beberapa bentuk formulasi Trichoderma spp terhadap serangan $F$. oxysporum f.sp. lycopersici (Fol) dapat dilihat pada Tabel 2.

Tabel 2. Rata-rata Masa Inkubasi akibat Aplikasi Beberapa Bentuk Formulasi Trichoderma spp terhadap Serangan Fol .

\begin{tabular}{l|c}
\multicolumn{1}{c|}{ Perlakuan } & Masa Inkubasi (HSI) \\
\hline Bentuk Formulasi Trichoderma spp & 6.90 \\
\hline F0 (Kontrol) & 7.30 \\
F1 (Formulasi pelet) & 6.60 \\
F2 (Formulasi jagung) & 7.70 \\
F3 (Formulasi cair) & \\
\hline
\end{tabular}

Pada Tabel 2, secara statistik menunjukkan aplikasi beberapa bentuk formulasi Trichoderma spp pada satu minggu sebelum inokulasi Fol tidak berpengaruh nyata terhadap masa inkubasi tanaman tomat. Hal ini dikarenakan pada saat inokulasi Fol terjadi curah hujan yang tinggi yang mengakibatkan kelembaban meningkat dengan suhu rata-rata pada saat penelitian mencapai $25-31^{\circ} \mathrm{C}$, akibatnya masa inkubasi cepat terjadi dan menyerang semua tanaman dengan rata-rata masa inkubasi 7 Hari Setelah Inokulasi (HSI). Hal ini membuktikan 
keadaan lingkungan ini sesuai dengan pernyataan Djaenuddin (2011), yang menyimpulkan bahwa suhu yang optimum untuk perkembangan patogen Fol yaitu pada suhu kisaran 20$30^{\circ} \mathrm{C}$. Sehingga kondisi ini diduga mengakibatkan perkembangan laju pertumbuhan Fol melebihi pertumbuhan Trichoderma spp.

Berdasarkan pernyataan Sudantha (1993) bahwa jumlah inokulum di dalam tanah sangat mempengaruhi daya infeksi. Sehingga hal ini menandakan bahwa pada aplikasi pertama Trichoderma spp yaitu 1 minggu sebelum inokulasi Fol ,jumlah inokulum cendawan Trichoderma spp belum mampu bekerja efektif untuk menghambat perkembangan Fol pada tahap awal pertumbuhan tanaman tomat.

\section{Persentase Tanaman Layu}

Hasil pengamatan terhadap persentase tanaman layu menunjukkan bahwa aplikasi beberapa formulasi Trichoderma spp tidak berpengaruh nyata terhadap persentase tanaman layu pada 35 dan 42 HSI dan berpengaruh nyata pada 49 HSI. Rata-rata persentase tanaman layu akibat aplikasi beberapa formulasi Trichoderma spp terhadap serangan Fol dapat dilihat pada Tabel 3.

Tabel 3. Rata-rata Persentase Tanaman Layu akibat Aplikasi Beberapa Bentuk Formulasi Trichoderma spp terhadap Serangan Fol.

\begin{tabular}{lccc}
\hline & \multicolumn{3}{c}{ Persentase Tanaman Layu (Arc $\sin \sqrt{\mathrm{x}}$ ) } \\
\cline { 2 - 4 } & 35 HSI & 42 HSI & 49 HSI \\
\hline Bentuk Formulasi Trichoderma $\mathrm{spp}$ & & & \\
\hline F0 (Kontrol) & 53.82 & 56.82 & $62.82 \mathrm{c}$ \\
F1 (Formulasi pelet) & 21.36 & 21.36 & $33.00 \mathrm{a}$ \\
F2 (Formulasi jagung) & 36.18 & 36.18 & $48.00 \mathrm{abc}$ \\
F3 (Formulasi cair) & 27.36 & 27.36 & $45.00 \mathrm{ab}$ \\
\hline BNT $_{0.05}$ & - & - & 17.55 \\
\hline
\end{tabular}

Keterangan: Angka-angka yang diikuti huruf yang sama pada kolom yang sama tidak berpengaruh nyata pada taraf 5\% (Uji BNT 0.05); HSI (Hari Setelah Inokulasi).

Tabel 3 menunjukkan bahwa persentase tanaman layu tertinggi dijumpai pada hasil perlakuan kontrol (F0) dengan nilai rata-rata $62.82 \%$ pada minggu terakhir pengamatan. Dari hasil uji statistik dapat disimpulkan bahwa perlakuan berbentuk formulasi pelet (F1) tidak menunjukkan pengaruh yang nyata jika dibandingkan dengan hasil perlakuan bentuk formulasi jagung (F2) serta bentuk formulasi cair (F3) namun menunjukkan pengaruh yang nyata jika dibandingkan dengan hasil perlakuan kontrol (F0).

Persentase tanaman layu yang rendah menandakan bahwa perlakuan bentuk formulasi pelet (F1) T. harzianum mampu menghambat penyakit layu Fusarium. Hal ini menunjukkan bahwa $T$. harzianum yang diformulasikan ke dalam bentuk pelet dapat mencegah dan menurunkan aktivitas patogen Fol dalam merusak jaringan tanaman. Hal ini sesuai dengan pernyataan Andriani et al. (2012), bahwa formulasi berbentuk pelet memiliki struktur semi padat dapat memungkinkan bahan aktif $T$. harzianum tidak mudah hilang oleh sinar matahari maupun air hujan. Pada saat pelaksanaan penelitian yaitu Desember 2016 - Maret 2017 hujan turun hampir setiap hari, sehingga pada kondisi demikian diduga formulasi dalam bentuk pellet bekerja lebih efektif. 
Selain pengaruh dari faktor cuaca, diduga juga bahwa komposisi yang terdapat pada formulasi pelet (F1) juga mampu merangsang pertumbuhan T.harzianum lebih baik. Hal ini didukung oleh hasil penelitian Zikriah (2015) yang menyimpulkan bahwa komposisi pada formulasi pelet daun katuk mempunyai nutrisi lebih lengkap untuk mendukung pertumbuhan T.harzianum.

Cendawan antagonis Trichoderma spp mempunyai mekanisme penghambatan terhadap patogen melalui berbagai cara, yaitu kompetisi nutrisi dan ruang, terjadinya kontak langsung, menghasilkan senyawa metabolit yang menghambat spora patogen, serta antibiosis untuk mematikan sel patogen dan sintesis toksik (Benitez et al., 2004). Harjono dan Widyastuti (2001) menyatakan, bahwa Trichoderma spp menggunakan bantuan enzim pendegradasi dinding sel yaitu kitinase, protease serta glukanase untuk melakukan proses penetrasi ke dalam dinding sel patogen dan selanjutnya menggunakan hifa inang sebagai sumber makanan. Pada saat melilit, Trichoderma spp menghasilkan enzim untuk melakukan penetrasi ke dinding sel inang, selain itu trichoderma spp juga mampu menghasilkan antibiotik seperti gliotoksin serta viridian. Sehingga hal ini menandakan bahwa Trichoderma spp mampu berperan pada aktivitas mikoparasit terhadap patogen-patogen, terutama cendawan Fol dalam penelitian ini.

Persentase tanaman layu tertinggi terjadi pada perlakuan kontrol (F0) tidak terdapat agens antagonis untuk menghambat perkembangan Fol, sehingga Fol dengan leluasa masuk melalui jaringan akar kemudian jaringan pembuluh lalu menggunakan jaringan xylem untuk mempercepat kolonisasi pada tanaman yang mengakibatkan kelayuan yang sesuai dengan ciri-cirinya (Wongpia dan Lomthaisong, 2010).

\section{Tinggi Tanaman Tomat}

Hasil pengamatan terhadap tinggi tanaman tomat menunjukkan bahwa aplikasi beberapa bentuk formulasi tidak berpengaruh nyata pada 7 dan 14 HSI, namun berpengaruh nyata pada 21 HSI. Rata-rata tinggi tanaman tomat akibat aplikasi beberapa formulasi Trichoderma spp terhadap serangan Fol dapat dilihat pada Tabel 4.

Tabel 4. Rata-rata Tinggi Tanaman Tomat akibat Aplikasi Beberapa Bentuk Formulasi Trichoderma spp terhadap Serangan Fol.

\begin{tabular}{lccc}
\hline \multirow{2}{*}{ Perlakuan } & \multicolumn{3}{c}{ Rata-rata Tinggi Tanaman } \\
\cline { 2 - 3 } & 7 HSI & 14 HSI & 21HSI \\
\hline Bentuk Formulasi Trichoderma spp & & & \\
\hline F0 (Kontrol) & 33.33 & 44.64 & $64.55 \mathrm{a}$ \\
F1 (Formulasi pelet) & 34.28 & 46.43 & $72.08 \mathrm{~b}$ \\
F2 (Formulasi jagung) & 31.07 & 43.04 & $66.31 \mathrm{ab}$ \\
F3 (Formulasi cair) & 35.52 & 47.55 & $71.68 \mathrm{~b}$ \\
\hline BNT $_{0.05}$ & - & - & 6.13 \\
\hline
\end{tabular}

Keterangan: Angka-angka yang diikuti huruf yang sama pada kolom yang sama tidak berpengaruh nyata pada taraf 5\% (Uji BNT 0.05); HSI (Hari Setelah Inokulasi).

Tabel 4 dapat dilihat bahwa perlakuan beberapa formulasi Trichoderma spp pada 21 HSI menunjukkan bahwa nilai rata-rata tertinggi untuk tinggi tanaman tomat dijumpai pada hasil perlakuan bentuk formulasi pelet (F1) yaitu $72.08 \mathrm{~cm}$ dan diikuti dengan hasil perlakuan bentuk formulasi cair (F3) yaitu $71.68 \mathrm{~cm}$ yang tidak berpengaruh nyata dengan hasil perlakuan bentuk formulasi jagung (F2) yaitu $66.31 \mathrm{~cm}$, namun berpengaruh nyata dengan hasil perlakuan kontrol (F0) yang memiliki nilai rata-rata terendah yaitu $64.55 \mathrm{~cm}$. 
Perlakuan dengan menggunakan bentuk formulasi pelet (F1) dan bentuk formulasi cair (F3) mempunyai kemampuan yang baik secara nyata untuk meningkatkan tinggi tanaman jika dibandingkan dengan hasil perlakuan kontrol (F0). Herlina dan Dewi (2010) menyatakan bahwa Trichoderma spp dapat berfungsi untuk menstimulasi pertumbuhan dan agen hayati bagi tanaman. Spesies Trichoderma spp diantaranya seperti $T$. harzianum dan $T$. virens mampu memproduksi hormon indol acetic acid (IAA) dan berbagai hormon turunan dari auksin untuk merangsang pertumbuhan tanaman (Nurahmi et al., 2012).

\section{Berat Total Buah Tomat Per Tanaman}

Hasil pengamatan terhadap berat buah tomat per tanaman menunjukkan bahwa aplikasi beberapa bentuk formulasi Trichoderma spp tidak berpengaruh nyata terhadap berat buah tomat per tanaman. Rata-rata berat buah tomat per tanaman akibat aplikasi beberapa formulasi Trichoderma spp terhadap serangan Fol dapat dilihat pada Tabel 6.

Tabel 7. Rata-rata Berat total Buah Tomat Per Tanaman akibat Aplikasi Beberapa Bentuk Formulasi Trichoderma spp terhadap Serangan Fol.

\begin{tabular}{l|c}
\multicolumn{1}{c|}{ Perlakuan } & Berat Buah (trans $\sqrt{\mathrm{x}}$ ) \\
\cline { 1 - 1 } Bentuk Formulasi Trichoderma spp & 25.69 \\
\hline F0 (Kontrol) & 29.03 \\
F1 (Formulasi pelet) & 27.70 \\
F2 (Formulasi jagung) & 27.40 \\
F3 (Formulasi cair) & \\
\hline
\end{tabular}

Dari data diatas tersebut dapat disimpulkan bahwa bahan aktif Trichoderma spp belum mampu mempengaruhi berat total buah tomat per tanaman, hal ini diduga karena Trichoderma spp pada berbagi formulasi belum mampu merangsang fitohormon, sehingga tanaman tidak memiliki respon yang signifikan untuk meningkatkan hasil tanaman tomat.

Triyatno (2005) menyatakan bahwa T. harzianum mampu merangsang tanaman dengan memproduksi hormon asam giberelin (GA3), asam indol asetat (IAA) dan benzyl amino purin (BAP) dalam jumlah yang besar sehingga pertumbuhan tanaman lebih optimum. Selain itu Trichoderma spp dalam tanah juga dapat melarutkan unsur hara yang terdapat dalam tanah, kemudian juga mampu meningkatkan serapan serta translokasi hara sehingga mampu memberikan hasil produksi yang maksimal (Bhuvaneswari et al., 2014). Namun dalam penelitian ini dapat disimpulkan bahwa Trichoderma spp dalam berbagai formulasi belum mampu berperan baik sebagai fitohormon serta pupuk biologis sehingga tidak mampu meningkatkan secara signifikan jumlah berat total buah per tanaman.

\section{Persentase Batang yang Xylemnya Terdiskolorasi}

Hasil pengamatan terhadap persentase batang yang xylemnya terdiskolorasi menunjukkan bahwa aplikasi beberapa bentuk formulasi Trichoderma spp berpengaruh sangat nyata terhadap persentase batang yang xylemnya terdiskolorasi. Rata-rata persentase batang yang xylemnya terdiskolorasi akibat aplikasi beberapa bentuk formulasi Trichoderma spp terhadap serangan Fol dapat dilihat pada tabel 8. 
Tabel 8. Rata-rata Persentase Batang yang Xylemnya Terdiskolorasi akibat Aplikasi Beberapa Bentuk Formulasi Trichoderma spp terhadap Serangan Fol.

\begin{tabular}{l|c}
\multicolumn{1}{c|}{ Perlakuan } & $\begin{array}{c}\text { Persentase Xylem Terdiskolorasi } \\
(\text { Arc } \sin \sqrt{\mathrm{x}})\end{array}$ \\
\hline Bentuk Formulasi Trichoderma spp & $51.00 \mathrm{~b}$ \\
F0 (Kontrol) & $6.72 \mathrm{a}$ \\
F1 (Formulasi pelet) & $15.54 \mathrm{a}$ \\
F2 (formulasi jagung) & $21.36 \mathrm{a}$ \\
F3 (formulasi cair) & 22.88 \\
\hline BNT $_{0.05}$ &
\end{tabular}

Keterangan: Angka-angka yang diikuti huruf yang sama berbeda tidak nyata pada taraf 5\% (Uji BNT 0.05 )

Tabel 8 di atas menunjukkan bahwa persentase batang yang xylemnya terdiskolorasi terendah dijumpai pada hasil perlakuan berbentuk formulasi pelet $(\mathrm{F} 1)$ yaitu dengan nilai ratarata $6.72 \%$ kemudian diikuti dengan hasil perlakuan berbentuk formulasi jagung (F2) dan formulasi cair (F3) yaitu dengan nilai rata-rata $15.54 \%$ dan $21.36 \%$. Namun persentase batang yang xylemnya terdiskolorasi tertinggi dijumpai pada hasil perlakuan kontrol (F0) yaitu dengan nilai rata-rata $7.64 \%$ sehingga terdapat pengaruh yang nyata antara perlakuan berbentuk formulasi pelet (F1), formulasi jagung (F2) dan formulasi cair (F3) terhadap persentase batang yang xylemnya terdiskolorasi dibandingkan hasil perlakuan kontrol (F0).

Pada perlakuan kontrol (F0) tidak terdapatnya agen antagonis Trichoderma spp sehingga mengakibatkan Fol dengan mudah melakukan penetrasi ke dalam jaringan akar dan berkembang pada jaringan korteks, kemudian masuk ke jaringan xylem berkolonisasi di jaringan tersebut serta mengeluarkan toksin yang berupa likomarasmin, asam dehidrofusarik dan asam fusarik yang mengakibatkan perubahan warna (diskolorasi) pada jaringan xylem menjadi cokelat (Sastrahidayat, 2010).

Menurut Yunasfi (2002), Fusarium sp menghasilkan asam fusarat yang merupakan toksin yang larut dalam air yang akan bekerja untuk merusak permeabilitas membran kemudian menyebabkan aliran air akan terhambat pada tanaman. Hambatan tersebut mengakibatkan kematian pada tanaman akibat terjadinya layu patologis yang tidak bisa balik (irreversible).

\section{KESIMPULAN}

Perlakuan terbaik terdapat pada perlakuan aplikasi berbentuk formulasi pelet yang mampu menekan penyakit layu hingga $33.00 \%$, selain itu bentuk formulasi pellet dan formulasi cair juga mampu meningkatkan tinggi tanaman tomat, namun ketiga bentuk formulasi Trichoderma spp tersebut yaitu formulasi pelet, formulasi jagung serta formulasi cair mampu menghambat persentase batang yang xylemnya terdiskolorasi dengan baik.

\section{DAFTAR PUSTAKA}

Agrios G.N., 2005. Plant Pathology ( $3^{\mathrm{r}} \mathrm{r}$ edn.). Academic Press, New York. (Diterjemahkan Oleh Busnia, M. Ilmu Penyakit Tumbuhan (Edisi Ketiga) Gadjah Mada University Press, Yogyakarta. 
Alfizar, Marlina, N. Hasanah. 2011. Upaya Pengendalian Penyakit Layu Fusarium oxysporum Dengan Pemanfaatan Agen Hayati Cendawan FMA dan Trichoderma harzianum. J. Floratek $6: 8-17$.

Andriani, D., Elfina, Y. S., dan Venita, Y. 2012. Uji Antagonis Trichoderma pseudokoningii Rifai dalam Formulasi Biofungisida yang Mengandung Beberapa Bahan Organik Terhadap Jamur Ganoderma boninense Pat Secara In Vitro. Riau : Fakultas Pertanian Universitas Riau.

Bhuvaneswari, S. Reetha, R. Sivaranjani and K. Ramakrishnan. 2014. Effect of AM fungi and Trichoderma spesies as stimulations of growth and morphological character of chilli (Capsicum annum L.). International Journal of Current Microbiology and Applied Scienses, 3 (3): 447-445.

BPS. 2016. Produksi Tomat Provinsi Aceh,2013-2014. (Online). Diakses 23 Februari 2016.

Chamzurni T., M. A. Ulim, E. Diannur. 2010. Uji Ketahanan Beberapa Varietas Tomat Terhadap Penyakit Layu Fusarium. J. Agrista Vol. 14 No. 2.

Djaenuddin, N, 2011. Bioekologi dan Pengelolaan Penyakit Layu Fusarium. Balai Penelitian Tanaman Serealia. Maros.

Freeman S., A. Zveibil, H. Vintal, and M. Maymon. 2002. Isolation of non-pathogenic Mutants of Fusarium oxysporum f. sp. melonis for Biological Control of Fusarium wilt in Cucurbits. Phytopathology 92: 164-168.

Herlina, L. dan P. Dewi. 2010. Penggunaan Kompos Aktif Trichoderma harzianum dalam Meningkatkan Pertumbuhan Tanaman Cabai. Skripsi. Fakultas Matematika dan Ilmu Pengetahuan Alam. Universitas Negeri Semarang, Semarang.

Lewis JA. and GC. Papavizas. 1983. Production of Clamidospores and Conidia by Trichoderma sp. In Liquid and Solid Growth Media. Soil Biology and

Biochemistry. 15 (4): 351-357.

Liswarni YF, Rifai dan Fitriani. 2007. Efektivitas Beberapa Spesies Trichoderma Untuk Mengendalikan Penyakit Layu pada Tomat, Yang Disebabkan oleh Fusarium oxysporum f. sp Lycopersici Sacc. J Hort. 8(1):39-42.

Nurahmi, E., Susanna dan R. Sriwati .2012. Pengaruh Trichoderma terhadap perkecambahan dan pertumbuhan bibit kakao, tomat, dan kedelai. Jurnal Floratek 7: 57 - 65.

Rusli R. dan Trizelia., 2009, Perbanyakan Beauveria bassiana Pada Limbah Organik, Formulasi dan Uji Efektivitasnya Sebagai Bioinsektisida Untuk Pengendalian Hama Spodoptera exigua Hubner (Lepidoptera : noctuidae). Unand. Padang.

Saragih YS, FS. Silalahi dan AE. Marpaung. 2006. Uji Resistensi Beberapa Kultivar Markisa Asam Terhadap Layu Fusarium. J Hort. 16(4):321-326.

Sastrahidayat, I.R., 2010. Fitopatologi (Ilmu Penyakit Tumbuhan). Usaha Nasional. Surabaya.

Semangun H. 2001. Pengantar Ilmu Penyakit Tumbuhan. Yogyakarta: Gajah

Mada University Press.

Soekarno B. P. W., Surono dan Susanti. 2014. Formulasi Pelet Berbahan Aktif Trichoderma sp. dan Aplikasinya Terhadap Penyakit Rebah Kecambah Pada Tanaman Mentimun. J. Fitopatologi Vol. 10 No. 2. 
Susanna, T. Chamzurni dan A. Pratama . 2010. Dosis dan Frekuensi Kascing untuk Pengendalian Penyakit Layu Fusarium pada Tanaman Tomat. J. Floratek 5 : 152-163.

Triyatno, B.Y. 2005. Potensi beberapa Agensia Pengendali terhadap Penyakit Busuk Rimpang Jahe. Skripsi Fakultas Pertanian Universitas Jenderal Soedirman. Purwokerto.

Wibowo, A. 2005. Kemampuan Strain Bakteri Antagonis Terhadap Fusarium Penyebab Layu pada Tomat dalam Kolonisasi Perakaran Tomat. J. Perlindungan Tanaman Indonesia. 11 (2).

Wongpia A., dan K. Lomthaisong. 2010. Changes in the 2DE protein profiles of chilli pepper (Capsicum annuum) leaves in response to Fusarium oxysporum infection. ScienceAsia 36:259-270.

Yunasfi. 2002. Faktor-Faktor yang Mempengaruhi Perkembangan Penyakit dan Penyakit yang Disebabkan Oleh Jamur. Fakultas Pertanian Jurusan Ilmu Kehutanan Universitas Sumatera Utara. USU Digital Library. http://library.usu.ac.id/download/fp/hutanyunasfi.pdf.

Zikriah. 2015. Potensi Daun Katuk Dan Lamtoro Sebagai Nutrisi Cendawan Trichoderma sp. Pada Pelet Media Tumbuh Dalam Menekan Pertumbuhan Patogen Tular Tanah. Skripsi. Unsyiah. Banda Aceh. 